\title{
Serum endocan as a survival predictor for patients with liver cirrhosis
}

\author{
Nobuyuki Toshikuni MD PhD, Kazuaki Ozaki MD PhD, Joseph George PhD, Mikihiro Tsutsumi MD PhD
}

\begin{abstract}
N Toshikuni, K Ozaki, J George, M Tsutsumi. Serum endocan as a survival predictor for patients with liver cirrhosis. Can J Gastroenterol Hepatol 2015;29(8):427-430.
\end{abstract}

BACKGROUND: The relationship between endocan expression and outcome in patients with chronic liver disease is not fully understood. OBJECTIVE: To examine whether serum endocan level is predictive of outcome in patients with liver cirrhosis.

METHODS: A total of 68 patients with liver cirrhosis were enrolled. Outcome predictors were analyzed using the Cox proportional hazards model. The overall survival rates were calculated using the Kaplan-Meier method, and differences were evaluated using the log-rank test.

RESULTS: During the median follow-up period (7.1 years), nine patients had hepatocellular carcinoma (HCC) and 10 patients died. Of the deceased patients, nine died due to hepatic decompensation or associated conditions. No significant factors were found to be predictive of the occurrence of HCC. In contrast, an elevated serum endocan level $(\geq 2.0 \mathrm{ng} / \mathrm{mL}$; HR 2.34 [95\% CI 1.05 to 7.03$]$; $\mathrm{P}=0.037)$ and high Child-Pugh grade B/C (HR 2.65 [95\% CI 1.30 to $6.89 ; \mathrm{P}=0.006)$ were predictive of poor survival. Kaplan-Meier analysis revealed that the respective cumulative survival rates at five and 10 years were $97.1 \%$ and $87.4 \%$ in patients with serum endocan levels $<2.0 \mathrm{ng} / \mathrm{mL}$ and $85.8 \%$ and $64.4 \%$ in patients with levels $\geq 2.0 \mathrm{ng} / \mathrm{mL}$ $(\mathrm{P}=0.009)$, respectively. Moreover, the cumulative survival rates were significantly different among the patient groups divided according to serum endocan level and Child-Pugh grade $(\mathrm{P}=0.002)$.

CONCLUSION: These findings suggest that serum endocan level may be a survival predictor for patients with liver cirrhosis.

Key Words: Endocan; Liver cirrhosis; Survival
$\mathrm{C}$ ndocan is a soluble proteoglycan of $50 \mathrm{kDa}$ that is mainly produced $\mathrm{E}_{\text {by activated vascular endothelial cells }(1,2) \text {. Studies have shown }}$ that endocan expression levels are closely associated with survival in patients with certain types of cancers (3-8). In a study in which patients with hepatocellular carcinoma (HCC) underwent surgical treatment, survival was inversely associated with microvessel density as denoted by endocan level (4). Our recent study showed that an elevated serum endocan level was predictive of poor survival in HCC patients (7). In contrast, the relationship between endocan expression and outcome in patients with chronic liver disease is not fully understood. Recently, Nault et al (9) examined the relationship between serum proteoglycan levels and outcomes of Caucasian patients with alcoholic liver cirrhosis and found that an elevated serum endocan level was a significant predictor of poor survival. In the current study, we sought to clarify whether serum endocan level was predictive of the outcomes in Asian patients with liver cirrhosis of different causes.

\section{METHODS}

\section{Patients}

The study protocol was approved by the Ethics Committee of Kanazawa Medical University (Ishikawa, Japan; approval no. 217) and was conducted in accordance with the Declaration of Helsinki. The

\section{L'endocan sérique comme prédicteur de survie chez des patients atteints d'une cirrhose}

HISTORIQUE : On ne comprend pas pleinement le lien entre l'expression de l'endocan et les résultats cliniques chez les patients atteints d'une maladie hépatique chronique.

OBJECTIF : Examiner si le taux d'endocan sérique est prédicteur des résultats cliniques chez des patients atteints d'une cirrhose.

MÉTHODOLOGIE : Au total, 68 patients atteints d'une cirrhose ont participé à l'étude. Les chercheurs ont analysé les prédicteurs des résultats au moyen du modèle des risques proportionnels de Cox. Ils ont calculé le taux de survie global à l'aide de la méthode de Kaplan-Meier et évalué les différences à l'aide du test Mantel-Haenzel.

RÉSULTATS : Pendant la période de suivi médiane ( 7,1 ans), neuf patients ont souffert d'un carcinome hépatocellulaire $(\mathrm{CHC})$ et dix sont décédés. Neuf des patients décédés sont morts à cause d'une décompensation hépatique ou d'affections connexes. Aucun facteur significatif n'était prédicteur de la CHC. En revanche, un taux d'endocan sérique élevé ( $\geq 2,0 \mathrm{ng} / \mathrm{mL}$; RR 2,34 [95 \% IC 1,05 à 7,03]; $\mathrm{P}=0,037$ ) et un score $\mathrm{B}$ ou $\mathrm{C}$ de Child-Pugh élevé (RR 2,65 [95 \% IC $1,30$ à 6,$89 ; \mathrm{P}=0,006)$ étaient prédicteurs d'une piètre survie. L'analyse de Kaplan-Meier a révélé que les taux de survie cumulatifs respectifs au bout de cinq et dix ans s'élevaient à 97,1\% et 87,4\% chez les patients dont le taux d'endocan sérique était inférieur à 2,0 ng/mL et à $85,8 \%$ et $64,4 \%$ chez ceux dont le taux était d'au moins $2,0 \mathrm{ng} / \mathrm{mL}(\mathrm{P}=0,009)$. De plus, le taux de survie cumulatif différait considérablement entre les groupes de patients répartis en fonction de leur taux d'endocan sérique et de leur score de Child-Pugh $(\mathrm{P}=0,002)$.

CONCLUSION : D'après ces observations, le taux d'endocan sérique pourrait être un prédicteur de survie chez les patients atteints d'une cirrhose. patient cohort was the same as that enrolled in the authors' previous study (7). Patients who were admitted between June 1995 and March 2012 were enrolled. Each patient or a member of his/her family provided written informed consent. Liver cirrhosis was diagnosed based on the results of histological examination, or the combined results of clinical and imaging examinations. All patients had no history of treatment for HCC.

\begin{abstract}
Treatment for liver cirrhosis
Patients with hepatitis B virus (HBV)-related liver cirrhosis and those with compensated hepatitis $\mathrm{C}$ virus ( $\mathrm{HCV}$ )-related liver cirrhosis were recommended nucleos $(\mathrm{t})$ ide analogue therapy and interferon therapy, respectively. Alcoholic patients were encouraged to abstain from alcohol. Patients with nonalcoholic steatohepatitis (NASH) were primarily treated with diet therapy. Additionally, patients with primary biliary cholangitis were recommended treatment with ursodeoxycholic acid. Patients with hepatic decompensation (ascites and/or hepatic encephalopathy) were treated with the appropriate medication. Gastroesophageal varices were endoscopically treated, if necessary.
\end{abstract}

Measurement of serum endocan levels Serum endocan levels were measured using an endocan ELISA kit (EndoMark H1; Lunginnov SAS, France). 
TABLE 1

Baseline characteristics of patients with liver cirrhosis $(\mathrm{n}=68)$

\begin{tabular}{lc}
\hline Variable & \\
\hline Age, years & $64(27-85)$ \\
Sex, male/female, $\mathrm{n}$ & $36 / 32$ \\
Etiology, HBV/HCV/alcoholic/NASH/other, $\mathrm{n}$ & $9 / 29 / 23 / 5 / 2$ \\
Child-Pugh grade, A/B/C, $\mathrm{n}$ & $42 / 19 / 7$ \\
Serum alpha-fetoprotein, $\mathrm{ng} / \mathrm{mL}$ & $7.4(1.8-650)$ \\
Serum endocan, $\mathrm{ng} / \mathrm{mL}$ & $1.93(0.45-8.47)$ \\
\hline
\end{tabular}

Data presented as median (range) unless otherwise indicated. HBV Hepatitis $B$ virus; HCV Hepatitis C virus; NASH Nonalcoholic steatohepatitis

\section{Follow-up}

Patients underwent laboratory tests every one to three months, and imaging examinations every three to six months. HCC was diagnosed based on imaging findings and serum levels of alpha-fetoprotein and des-gamma-carboxy prothrombin (DCP), or by histological examination of biopsied specimens (10). When HCCs were detected, the patients underwent appropriate treatment options.

\section{Statistical analysis}

Baseline data from the patients are expressed as median (range). Fisher's exact test was used to compare categorical variables. To clarify predictors of the occurrences of HCC and mortality, statistical analysis was performed using the Cox proportional hazards model. The following variables were entered into the model as potential predictors: age ( $<70$ versus $\geq 70$ years), sex (female versus male), etiology of liver cirrhosis (nonviral versus viral), Child-Pugh grade (A versus B/C), serum alpha-fetoprotein level ( $<20$ versus $\geq 20 \mathrm{ng} / \mathrm{mL}$ ), serum endocan level $(<2.0$ versus $\geq 2.0 \mathrm{ng} / \mathrm{mL}$ ) and definitive therapy (success versus failure/not performed). To determine the cut-off value for serum endocan, the 25 th, 50 th, or 75 th percentile were tested to determine whether the values maximized the hazard ratios. Consequently, the value around the 50 th percentile $(2.0 \mathrm{ng} / \mathrm{mL})$ was chosen as the cut-off value. Definitive therapy was defined as follows: antiviral therapy for patients with HBV- or HCV-related liver cirrhosis and abstinence from alcohol for patients with alcoholic liver cirrhosis. Because definitive therapy for NASH remains unestablished, all cases of NASH were categorized as 'failure/not done'. Multivariate analysis was performed using variables with $\mathrm{P}<0.05$ in the univariate analysis; $\mathrm{P}<0.05$ was considered to be statistically significant. The overall survival rates were calculated using the Kaplan-Meier method, and differences were evaluated using the log-rank test.

\section{RESULTS}

The study cohort included 68 patients with liver cirrhosis (median age 64 years; range 27 to 85 years; 36 male and 32 female) (Table 1 ). The causes of liver cirrhosis were HBV infection $(n=9)$, HCV infection $(n=29)$, alcohol abuse $(n=23)$, NASH $(n=5)$ and others (primary biliary cholangitis and unknown cause) $(n=2)$. Child-Pugh grades included A $(n=42), B(n=19)$ and C $(n=7)$. The median follow-up period was 7.1 years (range 0.6 to 15.9 years). Fifteen patients were lost to follow-up. There was no significant difference in the ratios of patients lost to follow-up between those with serum endocan levels $<2.0 \mathrm{ng} / \mathrm{mL}$ (nine of 36 ) and those with levels of $\geq 2.0 \mathrm{ng} / \mathrm{mL}$ (six of 32) $(\mathrm{P}=0.573$ [Fisher's exact test]). Of the nine patients with HBVrelated liver cirrhosis, eight received nucleos(t)ide analogue therapy and all achieved undetectable viral loads. Of the 29 patients with HCV-related liver cirrhosis, three had a previous history of unsuccessful interferon therapy (pegylated interferon plus ribavirin). Of the remaining 26 patients, 14 underwent interferon therapy (six with interferon monotherapy, one with nonpegylated interferon plus ribavirin and seven with pegylated interferon plus ribavirin) after enrollment and five achieved a sustained virological response. Of the 23 patients with alcoholic liver cirrhosis, nine abstained from alcohol.

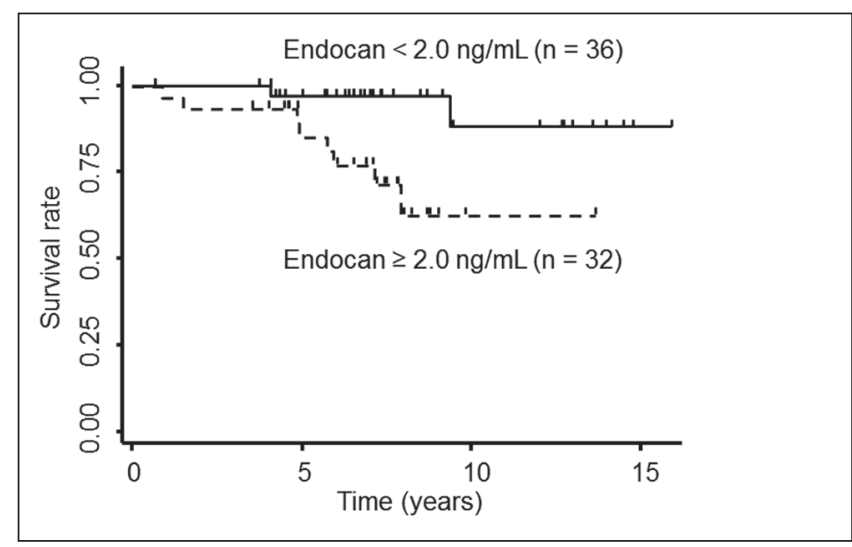

Figure 1) Kaplan-Meier survival analysis illustrating the different survival rates between the patients with serum endocan levels $<2.0 \mathrm{ng} / \mathrm{mL}$ and those with levels $\geq 2.0 \mathrm{ng} / \mathrm{mL}(P=0.009$ [log rank test])

During the follow-up period, nine patients had HCC and 10 patients died. As initial treatment for HCC, one patient received surgical treatment, two received percutaneous radiofrequency ablation and six underwent transcatheter arterial chemoembolization. The causes of death were liver failure $(n=7)$, rupture of gastric varices $(n=1)$, bacterial infection $(n=1)$ and HCC $(n=1)$.

Results of the analysis to identify outcome predictors yielded no significant factors that were found to be predictive of the occurrence of HCC (Table 2). An elevated serum endocan level and a high ChildPugh grade were significantly associated with mortality in the univariate analysis. Older age and successful definitive therapy tended to be associated with mortality. The multivariate analysis revealed that an elevated serum endocan level $(\geq 2.0 \mathrm{ng} / \mathrm{mL}$; HR 2.34 [95\% CI 1.05 to 7.03$]$; $\mathrm{P}=0.037$ ) and a high Child-Pugh grade (B/C; HR 2.65 [95\% CI 1.30 to 6.89]; $\mathrm{P}=0.006$ ) were significant predictors of poor survival (Table 2).

The Kaplan-Meier survival analysis revealed that the respective cumulative survival rates at five and 10 years were $97.1 \%$ and $87.4 \%$ in the patients with serum endocan levels $<2.0 \mathrm{ng} / \mathrm{mL}$ and $85.8 \%$ and $64.4 \%$ in those with levels $\geq 2.0 \mathrm{ng} / \mathrm{mL}(\mathrm{P}=0.009)$ (Figure 1$)$. The mortality rates according to Child-Pugh grade combined with serum endocan level were as follows: among patients with Child-Pugh grade A, the mortality rates were $0 \%$ (zero of 27 ) for those with serum endocan levels $<2.0 \mathrm{ng} / \mathrm{mL}$ and $13.3 \%$ (two of 15) for those with levels $\geq 2.0 \mathrm{ng} / \mathrm{mL}$. Among the patients with Child-Pugh grade B/C, the mortality rates were $22.2 \%$ (two of nine) for those with serum endocan levels $<2.0 \mathrm{ng} / \mathrm{mL}$ and $35.3 \%$ (six of 17) for those with levels $\geq 2.0 \mathrm{ng} / \mathrm{mL}$. One patient who died due to HCC was classified as Child-Pugh grade B/C and had a serum endocan level $<2.0 \mathrm{ng} / \mathrm{mL}$. The cumulative survival rates were significantly different among the patient groups divided according to serum endocan level and ChildPugh grade $(\mathrm{P}=0.002)$ (Figure 2$)$.

\section{DISCUSSION}

The results of the current study suggest that serum endocan level was predictive of survival in patients with liver cirrhosis. However, the proteoglycan level was not found to be associated with the occurrence of HCC. The same results were found in a recent study by Nault et al (9), who evaluated Caucasian patients with alcoholic liver cirrhosis. Our results were obtained from Asian patients with liver cirrhosis from different causes (mainly HCV infection and alcohol abuse), indicating that the results of the study by Nault et al (9) may be applicable regardless of ethnic group and cause of liver cirrhosis. The cut-off serum endocan levels slightly differed between the two studies $(5.0 \mathrm{ng} / \mathrm{mL}$ versus $2.0 \mathrm{ng} / \mathrm{mL})$. However, the findings from these two studies encourage further investigation to establish the use of the serum endocan level as a survival predictor for patients with liver cirrhosis. 


\begin{tabular}{|c|c|c|c|c|c|c|c|c|c|}
\hline \multirow[b]{3}{*}{ Variable } & \multirow{2}{*}{\multicolumn{3}{|c|}{$\begin{array}{c}\text { HCC } \\
\text { Univariate analysis }\end{array}$}} & \multicolumn{6}{|c|}{ Mortality } \\
\hline & & & & \multicolumn{3}{|c|}{ Univariate analysis } & \multicolumn{3}{|c|}{ Multivariate analysis } \\
\hline & $\begin{array}{c}\text { Relative } \\
\text { hazard }\end{array}$ & $95 \% \mathrm{Cl}$ & $\mathbf{P}^{*}$ & $\begin{array}{c}\text { Relative } \\
\text { hazard }\end{array}$ & $95 \% \mathrm{Cl}$ & $\mathbf{P}^{*}$ & $\begin{array}{c}\text { Relative } \\
\text { hazard }\end{array}$ & $95 \% \mathrm{Cl}$ & $\mathbf{P}^{*}$ \\
\hline \multicolumn{10}{|l|}{ Age, years } \\
\hline$<70(\mathrm{n}=48)$ & 1 & & & 1 & & & & & \\
\hline$\geq 70(n=20)$ & 0.85 & $0.19-2.16$ & 0.761 & 1.94 & $0.99-3.91$ & 0.053 & & & \\
\hline \multicolumn{10}{|l|}{ Sex } \\
\hline Female $(n=32)$ & 1 & & & 1 & & & & & \\
\hline Male $(n=36)$ & 0.65 & $0.29-1.32$ & 0.233 & 1.11 & $0.59-2.21$ & 0.735 & & & \\
\hline \multicolumn{10}{|l|}{ Etiology } \\
\hline Nonviral $(n=30)$ & 1 & & & 1 & & & & & \\
\hline Viral $(n=38)$ & 1.43 & $0.70-3.73$ & 0.346 & 1.05 & $0.56-2.07$ & 0.891 & & & \\
\hline \multicolumn{10}{|l|}{ Child-Pugh grade } \\
\hline$A(n=42)$ & 1 & & & 1 & & & & & \\
\hline$B / C(n=26)$ & 1.12 & $0.51-2.23$ & 0.750 & 3.00 & $1.50-7.75$ & 0.001 & 2.65 & $1.30-6.89$ & 0.006 \\
\hline \multicolumn{10}{|l|}{ Serum alfa-fetoprotein, $\mathrm{ng} / \mathrm{mL}$} \\
\hline$<20(\mathrm{n}=51)$ & 1 & & & 1 & & & & & \\
\hline$\geq 20(n=17)$ & 0.96 & $0.22-2.42$ & 0.947 & 1.3 & $0.60-2.47$ & 0.461 & & & \\
\hline \multicolumn{10}{|l|}{ Serum endocan, ng/mL } \\
\hline$<2.0(n=36)$ & 1 & & & 1 & & & & & \\
\hline$\geq 2.0(n=32)$ & 1.59 & $0.74-3.45$ & 0.227 & 2.63 & $1.27-7.04$ & 0.008 & 2.34 & $1.05-7.03$ & 0.037 \\
\hline \multicolumn{10}{|l|}{ Definitive therapy } \\
\hline Success $(n=22)$ & 1 & & & 1 & & & & & \\
\hline Failure/not performed $(n=46)$ & 1.28 & $0.65-2.82$ & 0.489 & 2.26 & $0.97-9.71$ & 0.060 & & & \\
\hline
\end{tabular}

Our recent study involving patients with liver cirrhosis with or without HCC revealed a positive correlation between the serum endocan level and Child-Pugh grade (7). Nevertheless, the current study demonstrated that these two factors are independent survival predictors for patients with liver cirrhosis. Of the 10 deceased patients, nine died due to hepatic decompensation or associated conditions (seven due to liver failure, one due to rupture of gastric varices and one from bacterial infection). These findings suggest that an elevated serum endocan level can be used to predict future or worsening hepatic decompensation and consequent mortality. In fact, among patients with Child-Pugh grade A, those who died had serum endocan levels $\geq 2.0 \mathrm{ng} / \mathrm{mL}$, while the mortality rates were higher in the patients with Child-Pugh grades B/C and serum endocan levels $\geq 2.0 \mathrm{ng} / \mathrm{mL}$ than in those with levels $<2.0 \mathrm{ng} / \mathrm{mL}$. The current study also suggests that the combination of the Child-Pugh grade and the serum endocan level can result in better prognostic stratification.

In the current study, we measured baseline serum endocan levels only once. For clinical use of this proteoglycan, whether these levels can substantially change within a short period of time should be clarified. Furthermore, whether the serum endocan level in each patient increases with the progression of liver cirrhosis should be examined in the future.

Little data regarding the causal relationship between increased endocan expression and the progression of liver cirrhosis are available. However, a recent study found that endocan induces the expression of proinflammatory cytokines, such as interleukin-8, monocyte chemotactic protein-1 (MCP-1) and tumour necrosis factor- $\alpha$, which are involved in mechanisms of chronic liver inflammation (11). This study also revealed that endocan stimulates nuclear factor kappa $\beta$ expression (11). Studies have shown that tumour necrosis factor- $\alpha$ and nuclear factor kappa $\beta$ stimulate liver inflammation and promote liver fibrosis by activating hepatic stellate cells $(12,13)$. Collectively, these effects of endocan on liver inflammation and fibrosis may cause the development of hepatic decompensation in patients with liver cirrhosis.

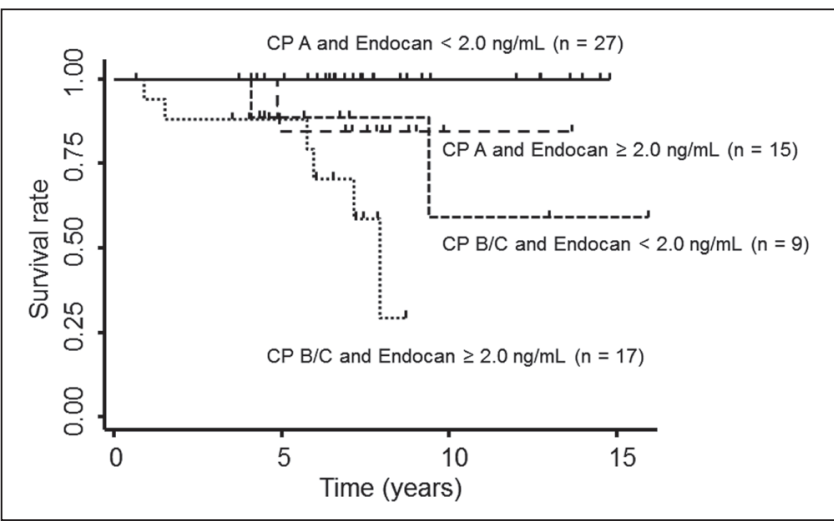

Figure 2) Kaplan-Meier survival analysis illustrating the different surviva rates among the patient groups divided according to serum endocan level and Child-Pugh (CP) grade ( $P=0.002$ [log rank test])

\section{CONCLUSION}

Our results suggest that measuring the serum endocan level is useful for predicting the survival of patients with liver cirrhosis. Furthermore, the combined use of the serum endocan level and the Child-Pugh grade enables better prognostic stratification of patients. Although these findings should be confirmed by further studies with a larger cohort of patients, the results provide new insights into managing patients with liver cirrhosis.

DISCLOSURES: The authors have no financial disclosures or conflicts of interest to declare.

ACKNOWLEDGEMENT: The authors thank Mr Mitsuru Araya for his excellent technical support. This study was fully funded by the Department of Hepatology, Kanazawa Medical University, Ishikawa, Japan. 


\section{REFERENCES}

1. Sarrazin S, Adam E, Lyon M, et al. Endocan or endothelial cell specific molecule-1 (ESM-1): A potential novel endothelial cell marker and a new target for cancer therapy. Biochim Biophys Acta 2006;1765:25-37.

2. Lassalle P, Molet S, Janin A, et al. ESM-1 is a novel human endothelial cell-specific molecule expressed in lung and regulated by cytokines. J Biol Chem 1996;271:20458-64.

3. Grigoriu BD, Depontieu F, Scherpereel A, et al. Endocan expression and relationship with survival in human non-small cell lung cancer. Clin Cancer Res 2006;12:4575-82.

4. Huang GW, Tao YM, Ding X. Endocan expression correlated with poor survival in human hepatocellular carcinoma. Dig Dis Sci 2009;54:389-94.

5. Ji NY, Kim YH, Jang YJ, et al. Identification of endothelial cell-specific molecule-1 as a potential serum marker for colorectal cancer. Cancer Sci 2010;101:2248-53.

6. El Behery MM, Seksaka MA, Ibrahiem MA, Saleh HS, El Alfy Y. Clinicopathological correlation of endocan expression and survival in epithelial ovarian cancer. Arch Gynecol Obstet 2013;288:1371-6.

7. Ozaki K, Toshikuni N, George J, et al. Serum endocan as a novel prognostic biomarker in patients with hepatocellular carcinoma. J Cancer 2014;5:221-30.
8. Zhao W, Sun M, Li S, Wang Y, Liu J. Biological and clinical implications of endocan in gastric cancer. Tumour Biol 2014;35:10043-9.

9. Nault JC, Guyot E, Laguillier C, et al. Serum proteoglycans as prognostic biomarkers of hepatocellular carcinoma in patients with alcoholic cirrhosis. Cancer Epidemiol Biomarkers Prev 2013;22:1343-52.

10. Makuuchi M, Kokudo N, Arii S, et al. Development of evidencebased clinical guidelines for the diagnosis and treatment of hepatocellular carcinoma in Japan. Hepatol Res 2008;38:37-51.

11. Lee W, Ku SK, Kim SW, Bae JS. Endocan elicits severe vascular inflammatory responses in vitro and in vivo. J Cell Physiol 2014:229:620-30.

12. Abhilash PA, Harikrishnan R, Indira M. Ascorbic acid suppresses endotoxemia and NF-kappaB signaling cascade in alcoholic liver fibrosis in guinea pigs: A mechanistic approach. Toxicol Appl Pharmacol 2014;274:215-24.

13. Liu C, Chen X, Yang L, Kisseleva T, Brenner DA, Seki E. Transcriptional repression of the transforming growth factor beta (TGF-beta) Pseudoreceptor BMP and activin membrane-bound inhibitor (BAMBI) by Nuclear Factor kappaB (NF-kappaB) p50 enhances TGF-beta signaling in hepatic stellate cells. J Biol Chem 2014;289:7082-91. 


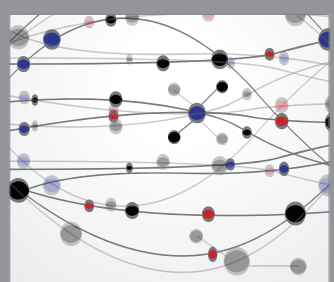

The Scientific World Journal
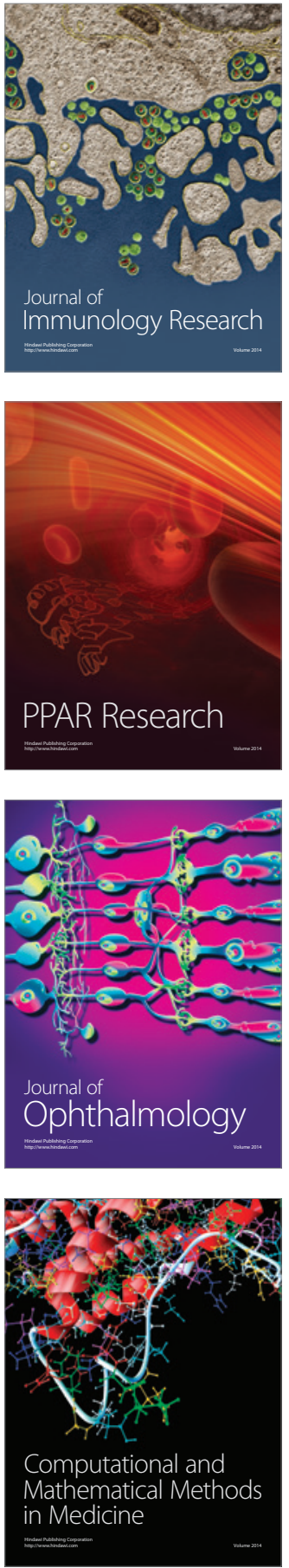

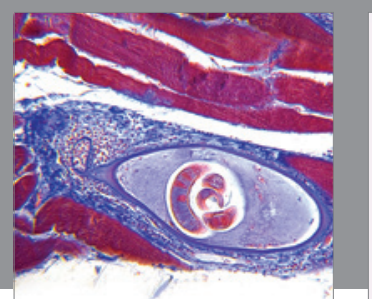

Gastroenterology Research and Practice

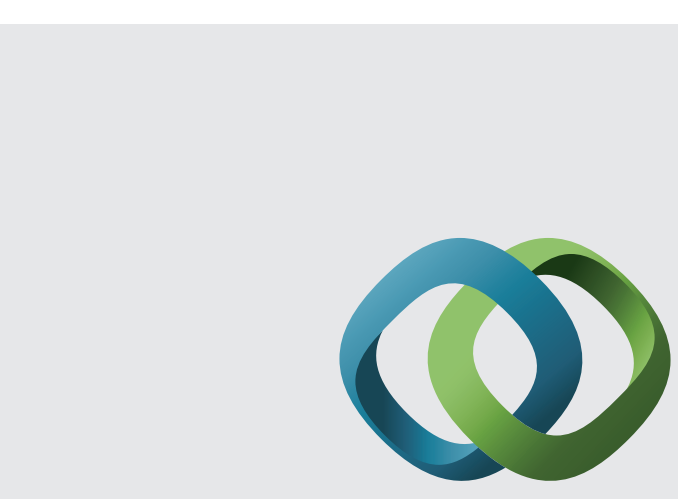

\section{Hindawi}

Submit your manuscripts at

http://www.hindawi.com
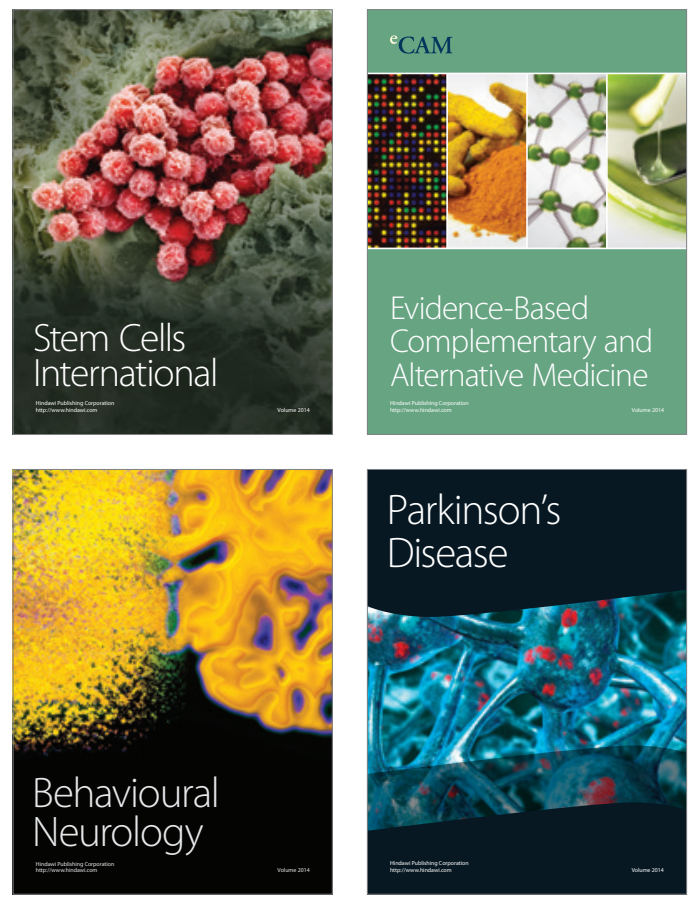
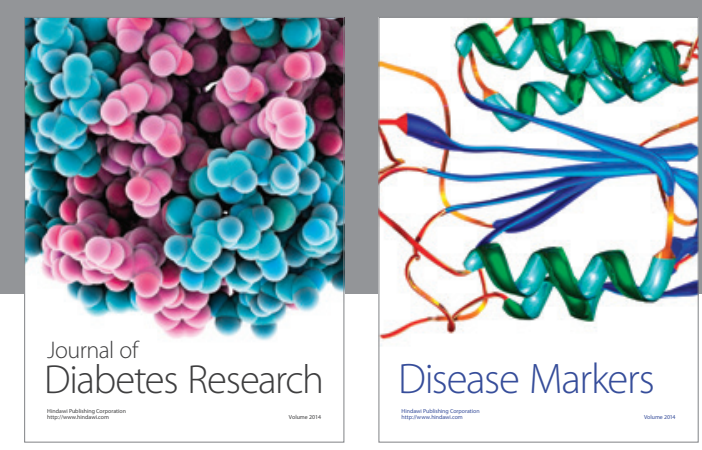

Disease Markers
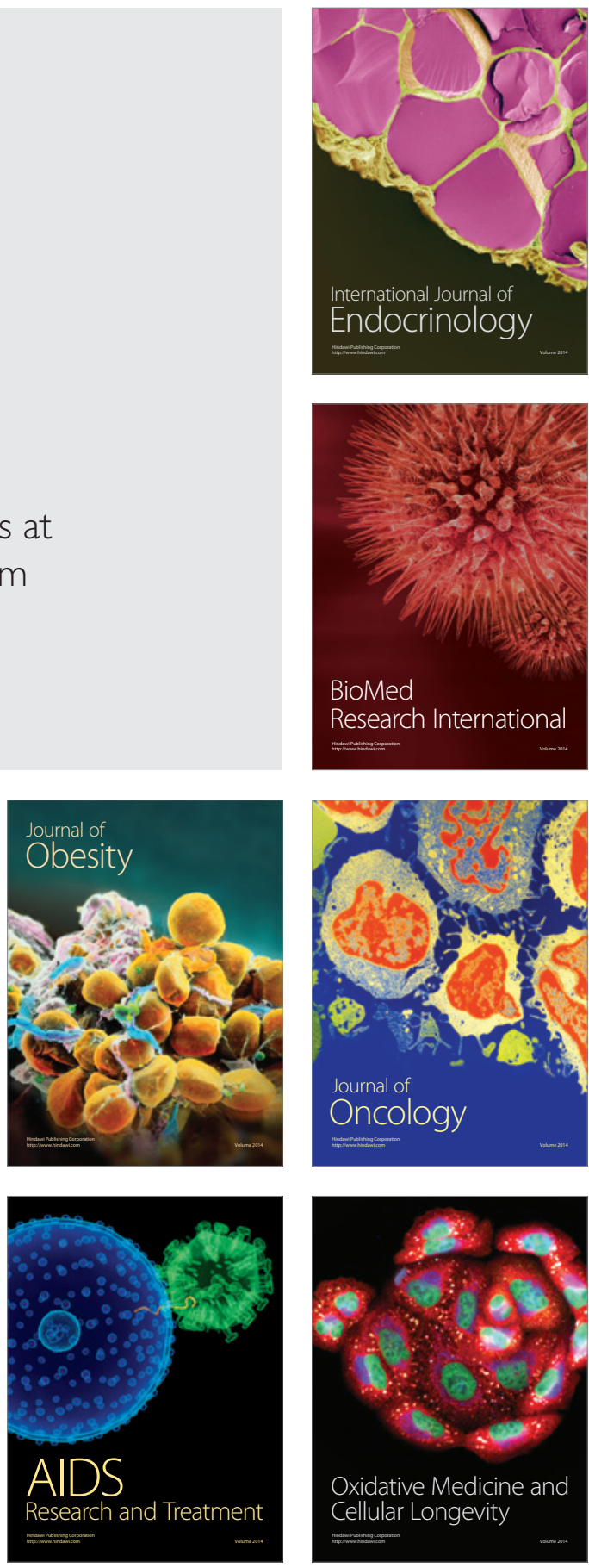